\title{
Епігеномні ефректи
} експозиції

вагітних щурів

Ао низької Аози біссренолу А

стосовно нейроендокринної системи чоловічого потомства $\mathrm{F}_{1}$ (коротке повідомлення)

\section{О.Г. Резніков , О.В. Сачинська, А. А. Лимарєва, Л. І. Полякова}

ДУ «Інститут ендокринології та обміну речовин ім. В. П. Комісаренка НАМН України», вул. Вишгородська, 69, Київ 04114, Україна

Мета: дослідження віддалених наслідків експозиції вагітних щурів лінії Вістар до низької дози бісфенолу А (БФА) шляхом визначення рівня стероїдних гормонів і статевої поведінки дорослого чоловічого потомства першої генерації.

Матеріал і методи дослідження. БФА у складі гелю Дорфмана вводили у шлунок тварин протягом останнього тижня вагітності, коли відбувається андрогензалежна статева диференціація мозку (СДМ), у щоденній дозі 25 мкг/кг м. т. (порогова тератогенна доза). Чоловічу статеву поведінку оцінювали за процептивними реакціями, тривалістю латентних і рефрактерних періодів та кількістю садок, інтромісій та еякуляцій в присутності рецептивної самиці. Жіночу статеву поведінку оцінювали за лордозними реакціями орхідектомованих та активованих введенням естрадіолу і прогестерону самців у присутності нормального самця. Нейроморфологічний аналіз секс-диморфної ділянки мозку - медіально-преоптичного ядра (МПЯ) гіпоталамуса проводили шляхом гістологічного дослідження і каріометрії нейронів.

Результати. Пренатально застосований БФА викликав вкрай незначне збільшення аногенітальної відстані у новонароджених тварин і не впливав на терміни статевого дозрівання. Рівні тестостерону і кортикостерону у плазмі крові самців 6-місячного віку не відрізнялись від контрольних показників. У 10-місячному віці всі піддослідні самці виявили вкрай ослаблену сексу-
Epigenomic effects of exposure of pregnant rats to low dose of bisphenol A regarding the neuroendocrine system of the male $F_{1}$ generation (short communication)

\section{Alexander G. Reznikov , Olga V. Sachynska, Anna A. Lymareva, Lyubov I. Polyakova}

SI "V. P. Komisarenko Institute of Endocrinology and Metabolism of the National Academy of Medical Sciences of Ukraine”, 69 Vyshgorodska St., Kyiv 04114, Ukraine

Aim: to study the long-term effects of exposure of pregnant Wistar rats to low dose of bisphenol A (BPA) by measuring the level of steroid hormones and sexual behavior of adult male offspring of the first generation.

Material and research methods. BPA as part of the Dorfman gel was gavaged during the last week of pregnancy, when androgendependent sexual brain differentiation occurs, in a daily dose of $25 \mathrm{mcg} / \mathrm{kg}$ b.w. (threshold teratogenic dose). Male sexual behavior was evaluated by proceptive reactions, the duration of latent and refractory periods, the number of mounts, intromissions and ejaculations in the presence of a receptive female. Female sexual behavior was assessed by lordosis reactions of orchidectomized and activated by the introduction of estradiol and progesterone males in the presence of a normal male. A neuromorphological analysis of the sex-dimorphic area of the brain, the medial preoptic nucleus of the hypothalamus, was performed by histological examination and karyometry of neurons.

Results. Prenatally administered BPA caused a very slight increase in the anogenital distance in newborn animals and did not affect the terms of puberty. The levels of testosterone and corticosterone in the blood plasma of males of 6 months of age did not differ from the control indices. At 10 months of age, all experimental males showed sharply weakened sexual motivation for mating with females, and in 
альну мотивацію до парування з самицями, а у 4 з 5 тварин копулятивні компоненти статевої поведінки були відсутні. У п'ятого самця також були відсутні еякуляції, а кількість садок без інтромісій та з інтромісіями була різко зменшена. У БФА-групі всі потомки демонстрували активну жіночу поведінку в присутності нормального самця, що виявлялось у лордозних реакціях і високому лордозному індексі. За даними гістологічного дослідження МПЯ, активність нейроцитів у чоловічого потомства БФА-експонованих самиць була значно зниженою, а розподіл іх ядер за об’ємом дещо відрізнявся від контролю.

Висновки. Отримані дані свідчать про епігенетичні порушення програми СДМ внаслідок пренатального впливу БФА у дозі, що не викликає суттєвих тератогенних ефектів. Це має бути враховано при визначенні потенційної небезпеки БФА для репродуктивного здоров'я.

Ключові слова: бісфенол А, пренатальна дія, самці щурів, статева поведінка, кортикостерон, тестостерон.

Для цитування: Резніков ОГ, Сачинська ОВ, Лимарєва АА, Полякова ЛІ. Епігеномні ефекти експозицї̈ вагітних щурів до низької дози бісбенолу А стосовно нейроендокринної системи чоловічого потомства $F_{1}$ (коротке повідомлення). Журнал Наиіональної академії медичних наук України. 2020;26(1-2):23-28. DOI: 10.37621/JNAMSU-2020-1-2-3.

Стаття надійшла до редакції 10.03.2019 року

Направлена на рецензування 27.11.2019 року

Прийнята до друку 08.12.2019 року

\section{ВІДОМОСТІ ПРО АВТОРІВ}

\section{ВІДДІЛ ЕНДОКРИНОЛОГІЇ РЕПРОДУКЦІї ТА АДАПТАЦІї}

Резніков Олександр Григорович - д. М. Н., проф., чл.-кор. НАН України, акад. НАМН України, завідувач відділу, ORCID: 0000-0002-0018-399X

Сачинська Ольга Володимирівна - к. б. н., провідний науковий співробітник, ORCID: 0000-0002-1767-4912;

Лимарєва Анна Анатоліївна - старший науковий співробітник, ORCID: 0000-0002-6963-5157;

Полякова Любов Іванівна - старший науковий співробітник, ORCID: 0000-0001-9957-7624.
4 from 5 animals, copulative components of sexual behavior were absent. There was no ejaculations in the 5th male as well, while numbers of the mounts without intromissions and ones with intromissions significantly reduced. In the BPA group, all descendants showed active female behavior in the presence of a normal male, which manifested in lordosis reactions and a high lordosis index. According to the histological study of medial preoptic nucleus, the activity of neurocytes in the male offspring of BPAexposed females was significantly reduced, and their nuclei volume distribution was some different from the control.

Conclusions. The data obtained indicate epigenetic disorders of the sexual brain differentiation program due to the prenatal exposure to BPA in dose that does not cause significant teratogenic effects. This should be taken into account when evaluating the potential hazard of BPA for reproductive health.

Key words: bisphenol A, prenatal effect, male rats, sexual behavior, corticosterone, testosterone.

For citation: Reznikov AG, Sachynska OV, Lymareva AA, Polyakova LI. Epigenomic effects of exposure of pregnant rats to low dose of bisphenol A regarding the neuroendocrine system of the male $F_{1}$ generation (short communication). Journal of the National Academy of Medical Sciences of Ukraine. 2020;26(1-2):23-28.

DOI: 10.37621/JNAMSU-2020-1-2-3.

The article was received on 10.03.2019

For review, 27.11.2019

Accepted for publication on 08.12.2019

\section{INFORMATION ABOUT AUTHORS}

\section{DEPARTMENT OF ENDOCRINOLOGY OF REPRODUCTION AND ADAPTATION}

Alexander G. Reznikov - Dr. Sci. (Medicine), Prof., Cor. Member of the NAS of Ukraine, Full Member of the NAMS of Ukraine, Head of the Department, ORCID: 0000-0002-0018-399X;

Olha V. Sachynska - Cand. Sci. (Biology), Leading Researcher, ORCID: 0000-0002-1767-4912;

Anna A. Lymareva - Senior Researcher, ORCID: 0000-0002-6963-5157;

Lyubov I. Polyakova - Senior Researcher, ORCID: 0000-0001-9957-7624.

\author{
Alexander G. Reznikov \\ ORCID:0000-0002-0018-399X \\ reznikov39@gmail.com
}




\section{ВСТУП}

Хімічні речовини, які використовують у промисловому виробництві, сільському господарстві, в пакувальних матеріалах, виробах медичного і косметичного призначення тощо, становлять неабияку загрозу здоров’ю людини. Чимало з них здатні порушувати діяльність ендокринних залоз, системи гормональної регуляції фізіологічних процесів через взаємодію з рецепторами гормонів або шляхом втручання в їх синтез і метаболізм. Ці речовини, яким притаманна гормоноподібна або антигормональна активність, отримали назву «ендокринні дизраптори» (ЕД). Вони $є$ визнаними етіологічними чинниками розладів репродуктивних функцій і поведінки, а також метаболічних порушень. ЕД вважають особливо небезпечними для вагітних та їхнього потомства, тому що вони здатні долати плацентарний бар'єр і негативно впливати на плід. Репродуктивна система плодів і дорослих $€$ найбільш уразливою до ЕД [1-3].

Одним з найбільш поширених ЕД є бісфенол А (БФА). Ця хімічна сполука продукується у величезній кількості і широко використовується у виробництві полікарбонатних пластмас, в композитних стоматологічних матеріалах, у покритті багатьох лікарських засобів, в епоксидних плівках, що вистилають місткості з напоями і харчовими продуктами. Продукування БФА у світі досягло величезних масштабів: у 2003 р. його валове виробництво досягло 2,2 млн тон, а його обсяг постійно зростає на 6-10\% щороку [4].

Досі немає одностайної думки щодо небезпеки використання БФА у пакетах, банках, пляшках для напоїв i харчових продуктів. У 2010 р. Федеральне агентство контролю харчових продуктів і ліків США визнало БФА як ймовірний патогенний агент для дітей. У Канаді його включено до списку потенційно небезпечних хімічних речовин. Натомість Європейська агенція з безпеки харчових продуктів вважає використання БФА для пакування напоїв і харчових продуктів безпечним для здоров'я споживачів.

В експериментах на щурах введення БФА у щоденних дозах 40-50 мкг/кг м. т. протягом вагітності та лактації послаблювало чоловічу статеву поведінку потомства самців по досягненню ними статевої зрілості $[5,6]$. Натомість у сто разів більші дози (5 мг/кг) парадоксальним чином не спричиняли негативного впливу на статеву поведінку [6].

Повідомлялось, що у чоловічого потомства щурів, матері яких отримували перорально БФА у добових дозах 2,5 або 25,0 мкг/кг м. т. з 6-го по 21-й день вагітності, збільшувався розмір секс-диморфного ядра преоптичної ділянки гіпоталамуса, що може свідчити про надмірну маскулінізацію мозку, що розвивається [7]. Прямо протилежний ефект отримано в результаті перинатального застосування БФА у дозах від 10 до 1000 мкг/кг м. т. [8], що може свідчити про порушення статевої диференціації мозку (СДМ). Залишалось невідомим, чим саме зумовлений негативний ефект низьких доз - вибірковим порушенням гормонозалежної СДМ чи нейротоксичним впливом БФА.

Метою цієї роботи було проведення морфологічного аналізу секс-диморфної ділянки гіпоталамуса та до- слідження гормонального профілю і статевої (чоловічої та жіночої) поведінки самців щурів, які були пренатально експоновані до низької дози ЕД в останній тиждень вагітності, який вважають критичним періодом СДМ [911].

\section{МАТЕРІАЛИ ТА МЕТОДИ}

Щурів лініі Вістар утримували у віваріі Інституту за стандартних умов температури, освітлення, харчування і 3 вільним доступом до питної води. Протокол досліджень отримав схвалення локальної біоетичної комісії. Самиць вагою 200-220 г із регулярними естральними циклами, які визначали шляхом щоденної мікроскопії вагінальних мазків, парували з самцями до появи в мазках сперматозоїдів. Цей день вважали першим днем вагітності. Протягом 15-21-го дня гестації тваринам $(\mathrm{n}=6)$ вводили в шлунок БФА («Sigma», США) у щоденній дозі 25 мкг/кг м. т. у складі гелю Дорфмана (0,5 \% гель карбоксиметилцелюлози у $0,9 \%$ розчині натрію хлориду з доданням твіну-80 i бензилового спирту). Контрольні тварини $(\mathrm{n}=7)$ отримували у такий самий спосіб гель Дорфмана.

У всіх новонароджених щуренят-самців вимірювали масу тіла та аногенітальну відстань на 2-й і 10-й дні після народження. Основні групи піддослідних і контрольних самців формували шляхом рандомізації. Термін статевого дозрівання визначали за опущенням сім'яників у мошонку. 6-місячних тварин декапітували і визначали вміст тестостерону в плазмі крові імуноферментним методом 3 використанням набору «Testosterone ELISA» («DRG», Hiмеччина) і вміст кортикостерону спектрофлюориметричним мікрометодом [12].

У цей же термін проводили дисекцію мозку для гістологічного дослідження секс-диморфної ділянки гіпоталамуса - медіально-преоптичного ядра (МПЯ). Фрагмент мозку, що відповідає розташуванню МПЯ, фіксували в рідині Буена, а фронтальні серійні зрізи товщиною 7 мкм забарвлювали азур-еозином за Паппенгеймом. На мікрофотографіях МПЯ вимірювали два взаємно перпендикулярні діаметри ядер нейроцитів і вираховували їх об’єм за формулою $\mathrm{V}=\mathrm{D} \times \mathrm{d} 2 \times \pi / 6$. У кожної тварини $(\mathrm{n}=5)$ вимірювали не менше 100 ядер нейроцитів.

Статеву поведінку досліджували у віці 10 міс. у темному приміщенні зі слабким червоним освітленням $[13,14]$. Тестування чоловічої статевої поведінки самців проводили двічі з тижневим інтервалом протягом 15 хв, жіночої протягом 10 хв. Деталі обох методик наведено у нашій попередній публікації [15].

Достовірність різниці між даними піддослідної та контрольної груп визначали за критеріями $t$ Стьюдента або $U$ Вілкоксона-Манна-Вітні. Різницю вважали статистично вірогідною при значенні $p<0,05$.

\section{РЕЗУЛЬТАТИ ТА ОБГОВОРЕННЯ}

Середня кількість щуренят у приплодах контрольних i піддослідних самиць була однаковою - 10,6 і 10,8 відповідно. Вкрай незначне збільшення відносної аногенітальної відстані у БФА-групі на 2-й (контроль - 
$(0,562 \pm 0,009)$ мм/г м. т., БФА - $(0,603 \pm 0,009)$ мМ/г м. т., $p<0,05)$ і 10-й (контроль - $(0,396 \pm 0,006)$ мм/г м. т., БФА $(0,418 \pm 0,006)$ мм/г м. т., $p<0,05)$ дні після народження було відсутнім у 6-місячних самців (контроль $(0,095 \pm 0,003)$ мм/г м. т., БФА - $(0,097 \pm 0,003)$ мм/г м. т., $p>0,05)$ завдяки подальшому зрощенню шва промежини. Ці зміни ймовірно пояснюються естрогеноподібною властивістю БФА.

Наші дані відрізняються від результатів дослідження, у якому БФА вводили щурам у сто разів більшій щоденній дозі 3 6-го дня вагітності до 21-го дня після народження і при цьому не побачили змін відносної аногенітальної відстані [16]. Це може вказувати на відсутність прямої залежності ефектів ЕД від дози, про що згадується у численних наукових працях стосовно переважної більшості досліджених ЕД.

Пренатально застосований БФА не впливав на терміни статевого дозрівання тварин. Дослідження рівня стероїдних гормонів плазми крові у 10-місячному віці не виявило порушень гормонального гомеостазу: рівень тестостерону в плазмі крові становив $(10,8 \pm 1,9)$ нмоль/л у БФА-групі проти $(10,1 \pm 1,4)$ нмоль/л у контрольній групі $(p>0,05)$, рівень кортикостерону в плазмі крові $(878,0 \pm 105,1)$ нмоль/л у БФА-групі проти $(1034,9 \pm 68,8)$ нмоль/л у контрольній групі $(p>0,05)$.

Дослідники статевої поведінки самців надають перевагу повторному тестуванню, коли «наївні» тварини набули певного сексуального досвіду. У другому тестуванні контрольні самці в присутності рецептивних самиць мали високий ступінь сексуальної мотивації, садки та інтромісії (табл.). Натомість у БФА-групі із п'яти самців один виявився сексуально неактивним, а четверо інших демонстрували значне подовження латентних періодів першої садки, зменшення кількості садок без інтромісій, відсутність інтромісій та еякуляцій, тобто відсутність проявів чоловічої копулятивної поведінки. Лише у одного самця було дві інтромісії за весь час тестування, а латентний період першої інтромісії різко збільшився (до 380 с).
При тестуванні жіночої статевої поведінки самців контрольної групи в присутності нормального самця не виявлено лордозних реакцій. Натомість вони були у великій кількості (в середньому 10,6) у всіх самців дослідної групи, в яких лордозний індекс склав 106,0. Проявів гомосексуальної поведінки в контакті з активним самцем у тварин обох груп не зафіксовано.

Таким чином, введення БФА у пороговій дозі щурам протягом 15-21-го днів вагітності майже повністю гальмує прояви копулятивних компонентів чоловічої статевої поведінки у дорослого чоловічого потомства. Разом 3 цим, воно порушує СДМ у вигляді появи чутливості нейроендокринних центрів до стимулювальної дії естрогену і лордозних реакцій. Важливо підкреслити, що пренатально застосований БФА зумовлює аномалії статевої поведінки у дорослих тварин на тлі нормального рівня тестостерону в плазмі крові.

Морфологічне дослідження МПЯ контрольних щурів виявило у його складі значну гетерогенність популяції нейроцитів. Переважали нейроцити, які мали великі перикаріони з високим ступенем вакуолізації цитоплазми, що $є$ ознакою посиленої функціональної активності клітин (рис. А). Середній об'єм ядер нейроцитів становив $(343,2 \pm 40,4)$ мкм $^{3}$ і варіював у широких межах.

Натомість в МПЯ тварин, матері яких отримували БФА, містилось набагато менше активованих нейроцитів (рис. Б). МПЯ складалось переважно з дрібних і середнього розміру нейроцитів, що мали помірно вакуолізовану цитоплазму. Нейроцити з великими вакуолями у перикаріонах були подинокі. Об'єм перикаріонів був значно меншим, ніж у контрольних тварин, що вказує на їхню зменшену функціональну активність. Також у МПЯ піддослідних тварин було менше гіперхромних нейронів 3 гомогенною цитоплазмою і тонкими відростками дендритів. Середній об’єм ядер нейроцитів статистично не відрізнявся від контролю і становив $(275,8 \pm 12,4)$ мкм $^{3}$ $(p>0,05)$. Не виявлено нейротоксичного впливу БФА на

\section{ТАБЛИЦЯ / TАВLE}

\section{ПОКАЗНИКИ ЧОЛОВІЧОЇ СТАТЕВОЇ ПОВЕДІНКИ САМЦІВ ЩУРІВ ВІКОМ 10 МІС. /}

INDICATORS OF MALE SEXUAL BEHAVIOR IN MALE RATS AGED 10 MONTHS

\begin{tabular}{|c|c|c|}
\hline Показник / Indicator & Контроль / Control (n= 5) & БФА / BPA $(n=4)$ \\
\hline \multicolumn{3}{|l|}{ Латентний період (c): / Latency period, s: } \\
\hline першої садки / first mount & $7,2(2-15)$ & $149(68-213) *$ \\
\hline першої інтромісії / first intromission & $17,0(6-33)$ & $380^{\#}$ \\
\hline першої еякуляції / first ejaculation & $285,2(179-371)$ & $>900$ \\
\hline $\begin{array}{l}\text { Постеякуляторний рефрактерний період (с) / } \\
\text { Post-ejaculatory refractory period, s }\end{array}$ & $403,4(297-535)$ & $>900$ \\
\hline \multicolumn{3}{|l|}{ Кількість: / Number: } \\
\hline садок без інтромісій / mounts without intromission & $5,8(4-7)$ & $2,0(0-3) *$ \\
\hline садок з інтромісіями / mounts with intromission & $18,4(14-27)$ & $0,5(0-2) *$ \\
\hline еякуляцій / еjaculations & $1,2(1-2)$ & 0 * \\
\hline
\end{tabular}

Примітки / Notes: Наведено середні дані та діапазон індивідуальних коливань (у дужках); " за непараметричним критерієм U Вілкоксона-Манна-Bimні порівняно з контрольними самиями / Presented are the mean values and the range of individual indices (in brackets). ${ }^{*}$ - One sexually active male. ${ }^{*} p<0.05$ by Wilcoxon-Mann-Whitney non-parametric U-criterion compared to control males. 


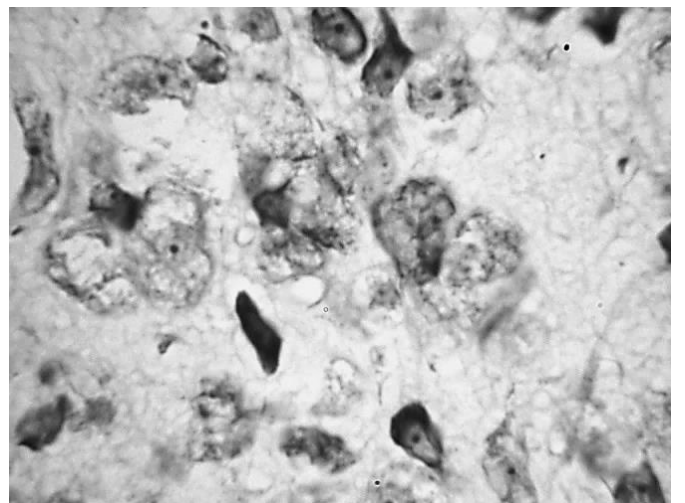

A

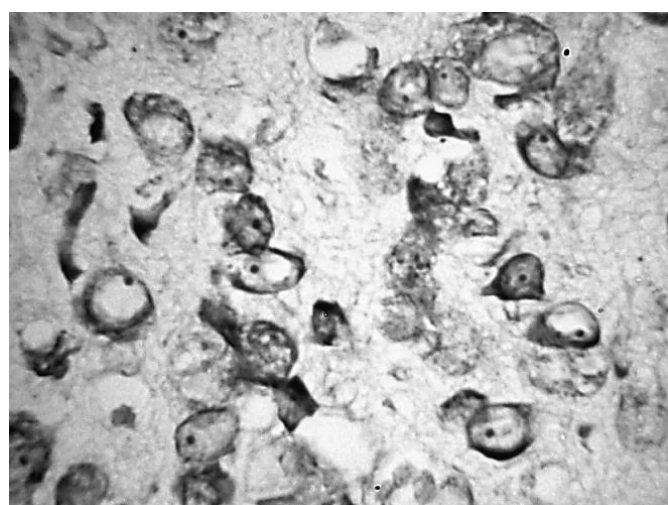

B
Рисунок / Figure. Мікрофотографії нейроцитів медіально-преоптичних ядер гіпоталамуса: А - контроль, В - бісфенол А. Забарвлення азуреозином, $\times 400$ / Micrographs of the neurocytes of hypothalamic medial preoptic nuclei: A - control, $B$ - bisphenol A. Staining with azur-eosin, $\times 400$. нейроцити МПЯ. Вочевидь, знайдені відхилення морфофункціонального стану пов'язані з впливом БФА на механізми СДМ.

Таким чином, результати морфологічного та каріометричного досліджень свідчать, що пренатальне застосування порогової дози БФА у критичний період СДМ призводить до зменшення функціональної активності нейроцитів МПЯ у самців. Ці зміни корелюють із гальмуванням чоловічої статевої поведінки, оскільки нейроендокринний центр іiі регуляції розташований саме у преоптичній ділянці гіпоталамуса гризунів. Имовірно, порушення андрогензалежної СДМ зумовлено антагоністичною дією БФА щодо тестикулярного тестостерону внутрішньоутробного плоду через наявність у цього ЕД естрогеноподібної активності.

\section{ВИСНОВКИ}

1 Внаслідок експозиції самиць щурів до порогової дози 1 БФА протягом останнього тижня вагітності у дорослого чоловічого потомства спостерігається майже повне гальмування чоловічої статевої поведінки і збереження чутливості нейроендокринних центрів репродукції до стимуляції жіночими статевими гормонами, що свідчить про тяжке порушення андрогензалежної СДМ.

2 Девіація статевої поведінки у самців спостерігається 2 на тлі нормальних рівнів тестостерону і кортикостерону в плазмі крові.

2 Морфофункціональним еквівалентом порушення 3 СДМ, індукованого пренатальною дією БФА, $є$ зменшена активність нейроцитів у МПЯ.

\section{СПИСОК ВИКОРИСТАНИХ ДЖЕРЕЛ / REFERENCES}

1. Reznikov AG. [Reproductive targets of endocrine disruptors]. Reprod Endocrinol. 2014 June;17(3):14-21. doi: 10.18370/23094117.2014.17.14-21. Russian.

2. Rattan S, Brehm E, Gao L, Flaws JA. Di(2Ethylhexyl) Phthalate Exposure During Prenatal Development Causes Adverse Transgenerational Effects on Female Fertility in Mice. Toxicol Sci. 2018 Jun 1;163(2):420-429.

DOI: $10.1093 /$ toxsci/kfy042.

3. Barakat R, Seymore T, Lin PP, Park CJ, Ko CJ. Prenatal exposure to an environmentally relevant phthalate mixture disrupts testicular steroidogenesis in adult male mice. Environ Res. 2019 May:172:194-201.

DOI: 10.1016/j.envres.2019.02.017.

4. Burridge E. Bisphenol A: Product profile. Eur Chem News. 2003;17:14-20.

5. Farabollini F, Porrini S, Della Seta D, Bianchi F, Dessi-Fulgheri F. Effects of perinatal exposure to bisphenol A on sociosexual behavior of female and male rats. Environ Health Perspect. 2002 Jun;110(Suppl 3):409-14.

DOI: 10.1289/ehp.02110s3409.

6. Jones BA, Shimell JJ, Watson NV. Pre- and postnatal bisphenol A treatment results in persistent deficits in the sexual behavior of male rats, but not female rats, in adulthood. Horm Behav. 2011 Feb;59(2):246-51. DOI: 10.1016/j.yhbeh.2010.12.006

7. He Z, Paule MG, Ferguson SA. Low oral doses of bisphenol $A$ increase volume of the sexually dimorphic nucleus of the preoptic area in male, but not female, rats at postnatal day 21. Neurotoxicol Teratol. 2012 May-Jun;34(3):331-7. DOI: 10.1016/j.ntt.2012.03.004.

8. McCaffrey KA, Jones $B$, Mabrey N, Weiss B, Swan $S H$, Patisaul HB. Sex specific impact of perinatal bisphenol A (BPA) exposure over a range of orally administered doses on rat hypothalamic sexual differentiation. Neurotoxicology. 2013 May;36:55-62. DOI: 10.1016/j.neuro.2013.03.001.

9. Reznikov AG. Hormone-neurotransmitter imprinting in the neuroendocrine control of reproduction. New York: Harwood Academic Publishers; 1994. $90 \mathrm{p}$.

10. Welsh M, Suzuki H, Yamada G. The masculinization programming window. Endocr Dev. 2014;27:17-27. DOI: 10.1159/000363609.

11. Reznikov AG. [Perinatal programming of disorders of endocrine functions and behavior]. Kyiv: Naukova dumka; 2019. 272 p. Ukrainian.
12. Balashov YuG. [Fluorimetric micromethod for determining corticosterone: Comparison with other methods]. Sechenov IM Fiziol Zh of USSR. 1990;76(2):280-3.Russian.

13. Holson RR, Gough B, Sullivan P, Badger T, Sheehan DM. Prenatal dexamethasone or stress but not ACTH or corticosterone alter sexual behavior in male rats. Neurotoxicol Teratol. 1995 Jul-Aug;17(4):393-401. DOI: 10.1016/08920362(94)00074-n.

14. Hull EM, Dominguez JM. Sexual behavior in male rodents. Horm Behav. 2007 Jun;52(1):45-55. DOI: 10.1016/j.yhbeh.2007.03.030.

15. Reznikov AG, Sachynska OV, Lymareva AA. [Age dynamics of changes in sexual behavio and androgen status of male rats caused by prenatal exposure to low dose dibutylphthalate]. Journal of the National Academy of Medical Sciences of Ukraine. 2019;25(3):260-7. Ukrainian.

16. Ferguson $S A$, Law CD Jr, Abshire JS. Developmental treatment with bisphenol A or ethinyl estradiol causes few alterations on early preweaning measures. Toxicol Sci. 2011 Nov;124(1):149-60. DOI: 10.1093/toxsci/kfr201. Erratum in: Toxicol Sci. 2013 Aug;134(2):428. 
PEЗЮME

\section{Эпигеномные эффекты экспозиции беременных крыс к низкой дозе бисфенола А \\ относительно нейроэнАокринной системы мужского потомства $\mathrm{F}_{1}$} (краткое сообщение)

\section{А. Г. Резников , О. В. Сачинская, А. А. Лимарева, Л. И. Полякова}

ГУ «Институт эндокринологии и обмена веществ им. В. П. Комиссаренко НАМН Украиныь», ул. Вычгородская, 69, Киев 04114, Украина

Цель: исследование отдаленных последствий экспозиции беременных крыс линии Вистар к низкой дозе бисфенола А (БФА) путём определения уровня стероидных гормонов и полового поведения взрослого мужского потомства первой генерации.

Материал и методы исследования. БФА в составе геля Дорфмана вводили в желудок животных в течение последней недели беременности, когда происходит андрогензависимая половая дифференциация мозга, в суточной дозе 25 мкг/кг м. т. (пороговая тератогенная доза). Мужское половое поведение оценивали по процептивным реакциям, продолжительности латентных и рефрактерных периодов, количеству садок, интромиссий и эякуляций в присутствии рецептивной самки. Женское половое поведение оценивали по лордозным реакциям орхидэктомированных и активированных введением эстрадиола и прогестерона самцов в присуствии нормального самца. Нейроморфологический анализ секс-диморфного участка мозга - медиально-преоптического ядра гипоталамуса проводили путем гистологического исследования и кариометрии нейронов.
Результаты. Пренатально введенный БФА вызывал весьма незначительное увеличение ано-генитального расстояния у новорожденных животных и не влиял на сроки полового созревания. Уровни тестостерона и кортикостерона в плазме крови самцов 6-месячного возраста не отличались от контрольных показателей. В 10-месячном возрасте все подопытные самцы проявили крайне ослабленную сексуальную мотивацию к спариванию с самками, а у 4 из 5 животных копулятивные компоненты полового поведения отсутствовали. У пятого самца также отсутствовали эякуляции, а количество садок без интромиссий и с интромиссиями было резко уменьшено. В БФА-группе все потомки демонстрировали активное женское поведение в присутствии нормального самца, что проявлялось в лордозных реакциях и высоком лордозном индексе. По данным гистологического исследования медиально-преоптического ядра, активность нейроцитов у мужского потомства БФА-экспонированных самок была значительно сниженной, а распределение их ядер по объему несколько отличалось от контроля.

Выводы. Полученные данные свидетельствуют об эпигенетических нарушениях программы половой дифференциации мозга вследствие пренатального воздействия БФА в дозе, которая не вызывает существенных тератогенных эффектов. Это должно быть учтено при оценке потенциальной опасности БФА для репродуктивного здоровья.

Ключевые слова: бисфенол А, пренатальное действие, самцы крыс, половое поведение, кортикостерон, тестостерон.

Для цитирования: Резников $А Г$, Сачинская $О B$, Лимарева $A A$, Полякова ЛИ. Эпигеномные эббекты экспозииии беременных крыс к низкой дозе бисфенола А относительно нейроэндокринной системь мужского потомства $F_{1}$ (краткое сообщение). Журнал Национальной академии медицинских наук Украины. 2020;26(1-2): 23-28. DOI: 10.37621/JNAMSU-2020-1-2-3.

Статья поступила в редакцию 10.03.2019 | Направлена на рецензирование 27.11.2019 | Принята в печать 08.12.2019 